\title{
Gastric Inhibitory Polypeptide Receptor
}

National Cancer Institute

\section{Source}

National Cancer Institute. Gastric Inhibitory Polypeptide Receptor. NCI Thesaurus. Code C26183.

Gastric inhibitory polypeptide receptor ( $466 \mathrm{aa}, \sim 53 \mathrm{kDa}$ ) is encoded by the human GIPR gene. This protein plays a role in $\mathrm{G}$ protein-coupled receptor signaling, insulin secretion, and glucose homeostasis. 